\title{
MSG Effects on Beta-Endorphin and Alpha-MSH in the Hypothalamus and Caudal Medulla
}

\author{
NORMAN E. ALESSI, PAUL QUINLAN \\ Department of Psychiatry, University of Michigan School of Medicine, Ann Arbor, MI 48109
}

AND

HENRY KHACHATURIAN

Department of Anatomy and Neurobiology, University of Tennessee College of Medicine, Memphis, TN 38163

\author{
Received 16 October 1987
}

\begin{abstract}
ALESSI, N. E., P. QUINLAN AND H KHACHATURIAN. MSG effects on beta-endorphin and alpha-MSH in the hypothalamus and caudal medulla PEPTIDES 9(4) 689-695, 1988.-Monosodium glutamate (MSG) was given to neonatal male rats to determine its effects on neurons containing beta-endorphin ( $\beta$-END) and alpha-melanocyte stımulatıng hormone ( $\alpha$-MSH) withın the basal hypothalamus (arcuate nucleus) and caudal medulla [nucleus tractus solitarius (NTS)] and on the levels of $\beta$-END and $\alpha$-MSH within these areas. Immunocytochemical studies demonstrated a reduction in the number of cells within the medial hypothalamic area (arcuate nucleus) among MSG-treated anımals versus salıne controls. MSG did not reduce the number of cell bodies withın the caudal medulla (NTS). MSG significantly reduced $\beta$-END and $\alpha$-MSH immunoreactive levels in the basal hypothalamus as determined by radiommunoassay. Whereas a significant reduction in the level of $\beta$-END occurred in the ventral caudal medulla (VCM), none occurred in the dorsal caudal medulla (DCM) In contrast, levels of $\alpha$-MSH increased significantly in the DCM among animals receiving MSG compared to control anımals. This study documents the contribution of beta-endorphin containıng neurons of the basal hypothalamus to areas of the caudal medulla. The effect of MSG on beta-endorphın and $\alpha$-MSH neurons in these areas and their differential effects on levels in the caudal medulla areas raises questions about the sites of ongin of these peptides.
\end{abstract}

Beta-endorphın Alpha-MSH Monosodium glutamate Arcuate nucleus Nucleus tractus solitarius

PERIKARYA containıng pro-opiomelanocortın (POMC) and its products, e.g., beta-endorphin ( $\beta$-END) and alphaMSH $(\alpha-\mathbf{M S H})$, are found in the arcuate nucleus and nucleus tractus solitarius (NTS) within the central nervous system $[1,9,11] . \beta$-END immunoreactive fibers are found in dorsal and ventral caudal medulla. Although the origin of these fibers is unknown, retrograde track tracing has demonstrated that cell bodies in the hypothalamus project to the NTS [19]. Radıoimmunoassay studıes in the adult rat, utilızıng either the entire caudal medulla or dorsal caudal medulla, indicate that the major POMC products are $\alpha$-MSH and $\beta$-END $[1,2,4]$. Given the potential physiological actions of either $\alpha$-MSH or $\beta$-END, it is important to discern not only their quantity but where these peptides may originate, i.e., the basal hypothalamus or the caudal medulla.

In the following study, monosodium glutamate (MSG) was administered to rats to assess the effects of MSG treatment on $\beta$-END and $\alpha$-MSH in the caudal medulla and the basal hypothalamus. The administration of MSG during development has been demonstrated to result in loss of perikarya in the medial basal hypothalamus (arcuate nucleus) and a reduction in the $\beta$-END and $\alpha$-MSH Im- munoreactivity in the brain $[5,13]$. The combination of these approaches, radioimmunoassay and immunocytochemistry, were utilızed to discern the relationship of the visible reduction in the number of perikarya with reduced levels of $\beta$-END and $\alpha$-MSH.

\section{METHOD}

\section{Monosodium Glutamate Treatment (MSG)}

Monosodium glutamate (MSG) was administered intraperitoneally to cross-fostered male Sprague-Dawley rats at postnatal days $2,4,6$ and 8 . The dosage was $4 \mathrm{mg}$ per gram body weight in a delivery volume of 100 microliters $[14,15]$. The control littermates received 100 microliters of $10 \%$ saline intraperitoneally at the same ages. E1ghteen (40\%) of forty-five MSG-treated animals survived to adulthood with the highest death rate occurring between postnatal days 6 and 12 . None of the control littermates died. Litters were housed in a twelve hour light-dark cycle (light from 0600 to 1800 ) with food and water provided ad lib. At postnatal day 21 , the MSG and control rats were weaned and placed in mixed groups of six per cage. 


\section{Tissue Collection}

The rats were housed in groups of up to six per cage untıl the ages of 95 and 105 days at which time they were killed by decapitation Six MSG and salıne anımals were randomly selected from these groups and served as the basis for the radioımmunoassay studies. Following decapitation the brains were removed from the skull and regions were dissected immediately [6]. Upon dissection, the pons-medulla tissue block was frozen on dry ice. The caudal medulla was dissected using the obex as the antenor boundary and the medulla-cord junction as the posterior boundary. The caudal medulla was then separated into ventral and dorsal regions using the central canal as the plane of division The collected tissue was stored at $-80^{\circ} \mathrm{C}$ Tissue extraction was performed as previously described [2]. The regions selected for study consisted of the hypothalamus, ventral medulla (VCM), and dorsal caudal medulla (DCM)

\section{Radoommunoassay of Beta-Endorphen and Alpha-MSH}

The $\beta$-END radioimmunoassay (RIA) procedure was performed as previously described [3]. The assay consisted of a three-day disequilibrium procedure using $4 \%$ sheep antirabbit globulin serum as the second antibody. The peptide used as the standard and for odination was human $\beta$-END 1-31 (Cat. No. 8616, Penınsula Lab, Belmont, CA) The antiserum was donated by Dr. Huda Akıl (Mental Health Research Institute, University of Michigan). The $\mathrm{IC}_{; 1}$ for the assay was $8.58 \pm 0.65$ femtomoles/tube and the sensitivity was $2.63 \pm 035$ femtomoles/tube The interassay coefficient of variation was $7.52 \%$ and the intraassay coefficient of varlation was $68 \%$.

The $\beta$-END antiserum is $100 \%$ crossreactive with its larger molecular weight precursors, POMC or betalipotropin The antiserum showed no cross reactivity with gamma-endorphın ( $\beta$-END 1-16), ACTH, $\alpha$-MSH, gamma-MSH, [Leu] or [Met] enkephalın, dynorphın related peptides or a number of nonopioid pituitary peptides A complete characterization of the antiserum can be found in Cahill et al. [3] The $\beta$-END immunoreactivity measured in the RIA was the sum total of $\beta$-END, beta-lipotropın, and POMC immunoreactivities

The $\alpha$-MSH assay procedure was performed as previously described [2] The assay consisted of a five-day disequilıbrium procedure using 5\% sheep antı-rabbit globulin serum as the second antibody. The peptide used as the standard and for iodination was $\alpha$-MSH (Cat No 7251, Peninsula Laboratories, Belmont, CA). The antisera (Number 24) was donated by Dr. Thomas O'Donohue (formerly of Monsanto) The final dilution for antisera was $1 / 30,000$ The $\mathrm{IC}_{50}$ for the assay was $14.86 \pm 0.61$ femtomoles/ tube and the sensitivity was $40 \pm 0.30$ femtomoles/tube. The interassay coefficient of variation was $153 \%$ The $\alpha-\mathrm{MSH}$ antisera is $100 \%$ crossreactive with $\alpha-\mathrm{MSH}$, des-acetyl $\alpha$-MSH, and deaminated $\alpha$-MSH. The antiserum was $00 \%$ crossreactive with ACTH 1-24, human ACTH 1-39, human $\beta$-END 61-91, human beta-lipotrophın and ACTH 1-10, ACTH 4-10 or ACTH 4-11 Protein levels were determined utilizing a standard procedure [12]. The Student's $t$-test for unparred samples was used to assess the levels of significance between sample means

\section{Colchicine Pretreatment}

To enhance the visualization of neuronal perikarya colchicine $(250 \mu \mathrm{g}$ in $10 \mu \mathrm{l} 09 \%$ salıne) was injected intracere- broventricularly into adult rats, MSG- or salıne-pretreated, from which brains were taken for immunocytochemistry. Only anımals whose brains were used for immunocytochemistry were given colchicine prior to sacrifice The main action of colchicine is inhibition of microtubule synthesis, resultıng in retardation of axonal transport and an accumulation of synthesized material in neuronal perikarya [7] For injection, each anımal was anesthetızed with sodıum pentobarbital (5-10 $\mathrm{mg}$ per animal), the skull exposed, and colchicine injected into the right lateral ventricle. The skull opening was filled in with bone wax and the scalp closed using wound clips. Animals were allowed to recover for 48 hours, and then sacrificed as described below.

\section{Immunoc ytochemustry of Beta-Endorphin}

Brain sections were prepared for immunocytochemistry as described previously [10] Rats were anesthetized with sodium pentobarbital $(50 \mathrm{mg} / \mathrm{kg})$ given intraperitoneally and placed on crushed ice. The cardıovascular system was flushed with $09 \%$ saline followed by perfusion with ice-cold $4 \%$ formaldehyde ( $\mathrm{pH} 7.4)$ in $01 \mathrm{M}$ phosphate buffer, for 30 mınutes. The brains were removed promptly and placed in the same fixative for an additional hour, after which they were transferred into $15 \%$ sucrose in phosphate-buffered salıne (PBS) and refrigerated overnight. Tissue blocks were frozen onto brass cryostat chucks with liquid nitrogen and sectioned in a cryostat at $-20^{\circ} \mathrm{C}$. Sections of $20 \mu \mathrm{m}$ thickness were thaw-mounted onto gelatın-coated slıdes and stored at $-80^{\circ} \mathrm{C}$.

Primary rabbit antiserum to $\beta$-END (gift of Dr. Stanley Watson, Mental Health Research Institute, University of Michigan) was diluted with $0.3 \%$ Triton X-100 in $002 \mathrm{M}$ PBS, added onto the sections, and allowed first to incubate for 1 hour at $37^{\circ} \mathrm{C}$, then overnight at $4^{\circ} \mathrm{C}$ After $3 \times 10$ minutes PBS washes, the sections were incubated with goat antrabbit serum (Arnel) for 30 minutes at $37^{\circ} \mathrm{C}$ and then at $4^{\circ} \mathrm{C}$ overnight. The sections were again washed in PBS, and incubated in successive steps with horseradish peroxidase (HRP) antiserum, followed by another PBS wash, and HRP enzyme (Sigma, Type VI) for 40 minutes, each at $37^{\circ} \mathrm{C}$ The slides were then washed in PBS and immersed in a solution of $0.03 \%$ hydrogen peroxide and $0125 \mathrm{mg} / \mathrm{ml}$ diamınobenzidine (Sigma) for 15 minutes with constant stırring. The sections were washed in distılled water, briefly osmicated ( $2 \%$ osmium tetroxide), washed, dehydrated through ethanols and xylenes and mounted in Permount Observations and photography were performed using a Leitz Orthoplan Microscope

\section{RESULTS}

Figure 1 shows the total body weights (grams) and whole brain wet weights (milligrams) of MSG and salıne groups of anımals The total body weights (mean \pm SEM) of the animals recelving MSG (340 \pm 14 grams) were significantly lower $(p<0.005)$ than animals receiving salıne $(419 \pm 17$ grams $)$ Brain wet weights were also significantly lower $(p<0005)$ in the MSG-treated animals (1,740 \pm 50 milligrams) compared to control anımals $(2,090 \pm 40$ milligrams). The pattern of the reduced brain wet weight in MSG animals was noted for the DCM and VCM, as well (Fig. 2). The DCM showed a significant reduction $(p<0.005)$, but a greater reduction was seen in the VCM with the values $2925 \pm 0.71$ milligrams among salıne control anımals versus $1938 \pm 15$ milligrams among the MSG animals $(p<00001)$. There was no significant 


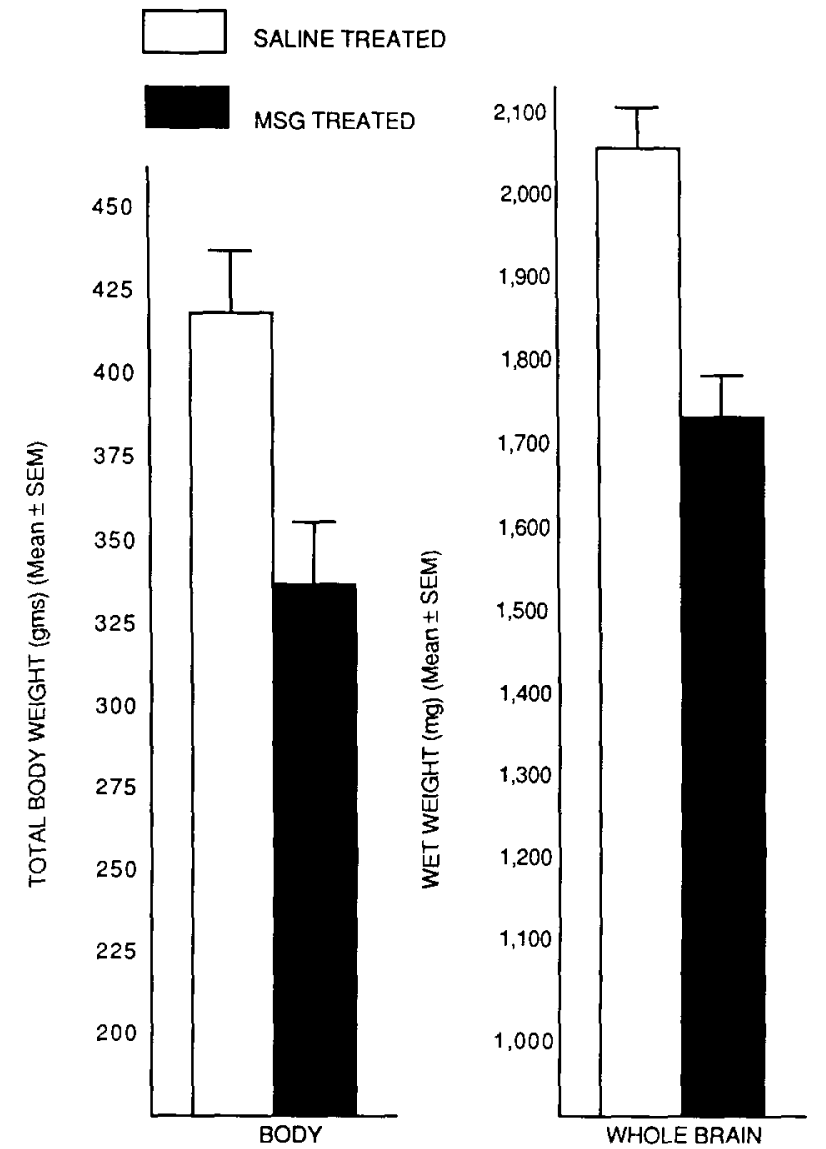

FIG 1 Total body weight (grams) and whole brain wet weight (milligrams) in MSG versus control rats Unshaded bar represents salıne control anımals, shaded bar represents MSG anımals $N=6$ per condition. gms $=$ grams, $\mathrm{mg}=$ miligrams

difference in hypothalamus wet weights between saline control (35.25 \pm 1.97 milligrams) and MSG- $(30.13 \pm 2.55$ milligrams) treated animals.

The Immunocytochemical study of $\beta$-END withın the hypothalamus and caudal medulla of saline control versus MSG rats is presented in Fig. 3. In Fig. 3A, the presence of $\beta$-END staining cell bodies is apparent in the arcuate nucleus of saline control animals. In Fig 3B, the reduction in cell number in the medial basal hypothalamus (arcuate nucleus) is prominent. Of note is the increase in size of perikarya contained within the lateral basal hypothalamic area. In comparison, the number of cell bodies within the caudal medulla were not reduced among MSG-treated animals versus saline control, nor did there appear to be an alteration in the size of the cell bodies, as was noted in the lateral hypothalamic $\beta$-END containing cells (Fig. 3C and D).

The values (mean \pm SEM) of $\beta$-END immunoreactivity in the anımals receiving salıne were 976.14 \pm 3.637 $\mathrm{fmol} / \mathrm{mg}$ protein for hypothalamus, $86.20 \pm 10.92 \mathrm{fmol} / \mathrm{mg}$ protein for the $\mathrm{VCM}$, and $44.49 \pm 4.51 \mathrm{fmol} / \mathrm{mg}$ protein for the DCM. The VCM had a significantly higher concentration of $\beta$-END immunoreactivity than the DCM $(p<0.005)$. Among the MSG-treated animals, $\beta$-END $1 \mathrm{~m}$ munoreactivity significantly decreased in the hypothalamus $(p<0.0005)$ and the VCM $(p<0.025)$ to $371.50 \pm 6090$ $\mathrm{fmol} / \mathrm{mg}$ proteın and $37.73 \pm 6.40 \mathrm{fmol} / \mathrm{mg}$ protein, respec-

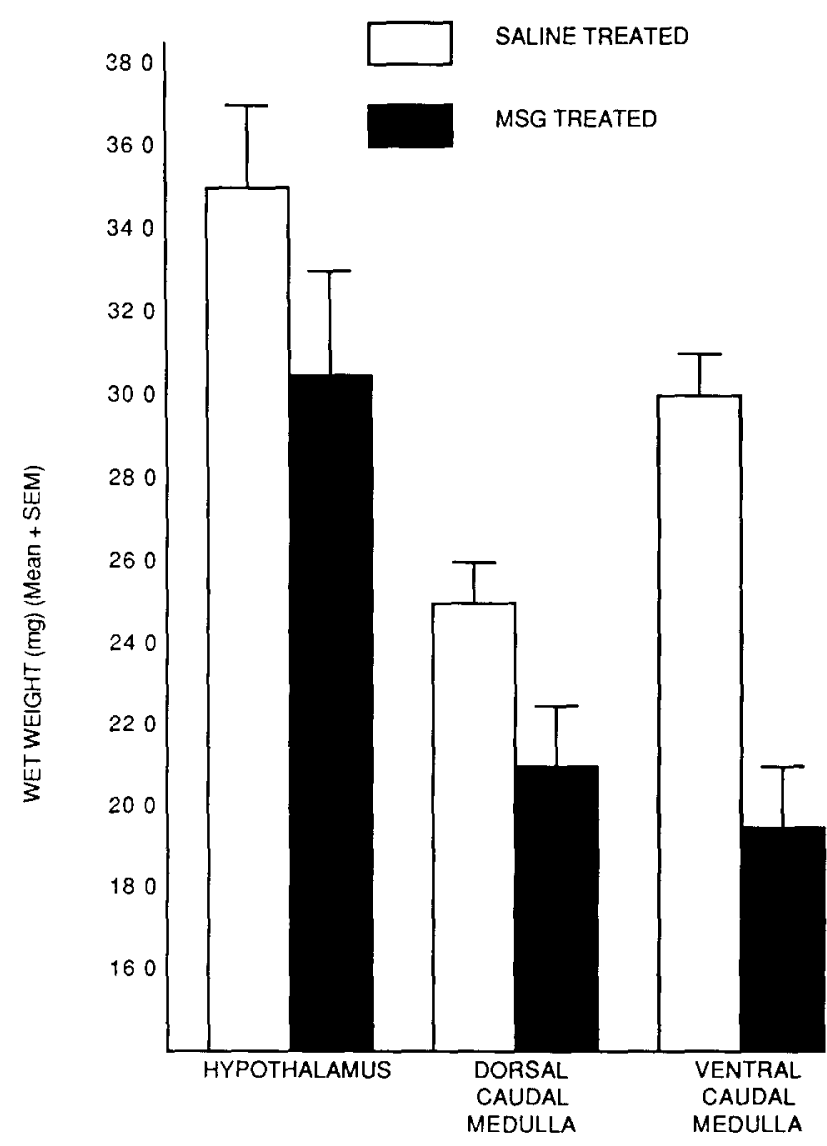

FIG 2 Wet weights (mılligrams) of hypothalamus, dorsal caudal medulla, and ventral caudal medulla of MSG versus control rats Unshaded bar represents salıne control anımals, shaded bar represents MSG animals $\mathrm{N}=6$ per area per condition $\mathrm{mg}=$ milligrams.

tively. $\beta$-END immunoreactivity in the DCM did not significantly decrease with $\beta$-END immunoreactivity being $36.34 \pm 6.90 \mathrm{fmol} / \mathrm{mg}$ protein (see Fig. 4).

The values (mean \pm SEM) of $\alpha$-MSH-like immunoreactive material in the anımals receiving salıne were $22928 \pm 43.53$ $\mathrm{fmol} / \mathrm{mg}$ protein for the hypothalamus, $29.51 \pm 4.33 \mathrm{fmol} / \mathrm{mg}$ protein for the $\mathrm{VCM}$, and $17.14 \pm 1.24 \mathrm{fmol} / \mathrm{mg}$ protein for the DCM. The VCM had a significantly higher concentration of $\alpha$-MSH than the DCM $(p<0.025)$. In the MSG-treated anımals, $\alpha$-MSH significantly decreased in the hypothalamus from $229.28 \pm 43.53$ to $85.31 \pm 6.48 \mathrm{fmol} / \mathrm{mg}$ protein $(p<$ 0.005 ). Whereas $\alpha$-MSH in the DCM significantly increased $(p<0.01)$ from $17.14 \pm 1.24$ to $28.28 \pm 3.79 \mathrm{fmol} / \mathrm{mg}$ proteın, levels withın the VCM did not significantly change $(p<$ N S.) (see Fig. 5).

\section{DISCUSSION}

The administration of monosodium glutamate (MSG) during development resulted in a decrease in the levels of $\beta$-END immunoreactivity and $\alpha$-MSH immunoreactivity in the medial basal hypothalamus. These results replicate earlier radioımmunoassay studies [9]. Although the $\beta$-END radıommunoassay results were paralleled by a decrease in the number of $\beta$-END staining cell bodies in the medial hypothalamus (arcuate nucleus), cell bodies in the lateral 


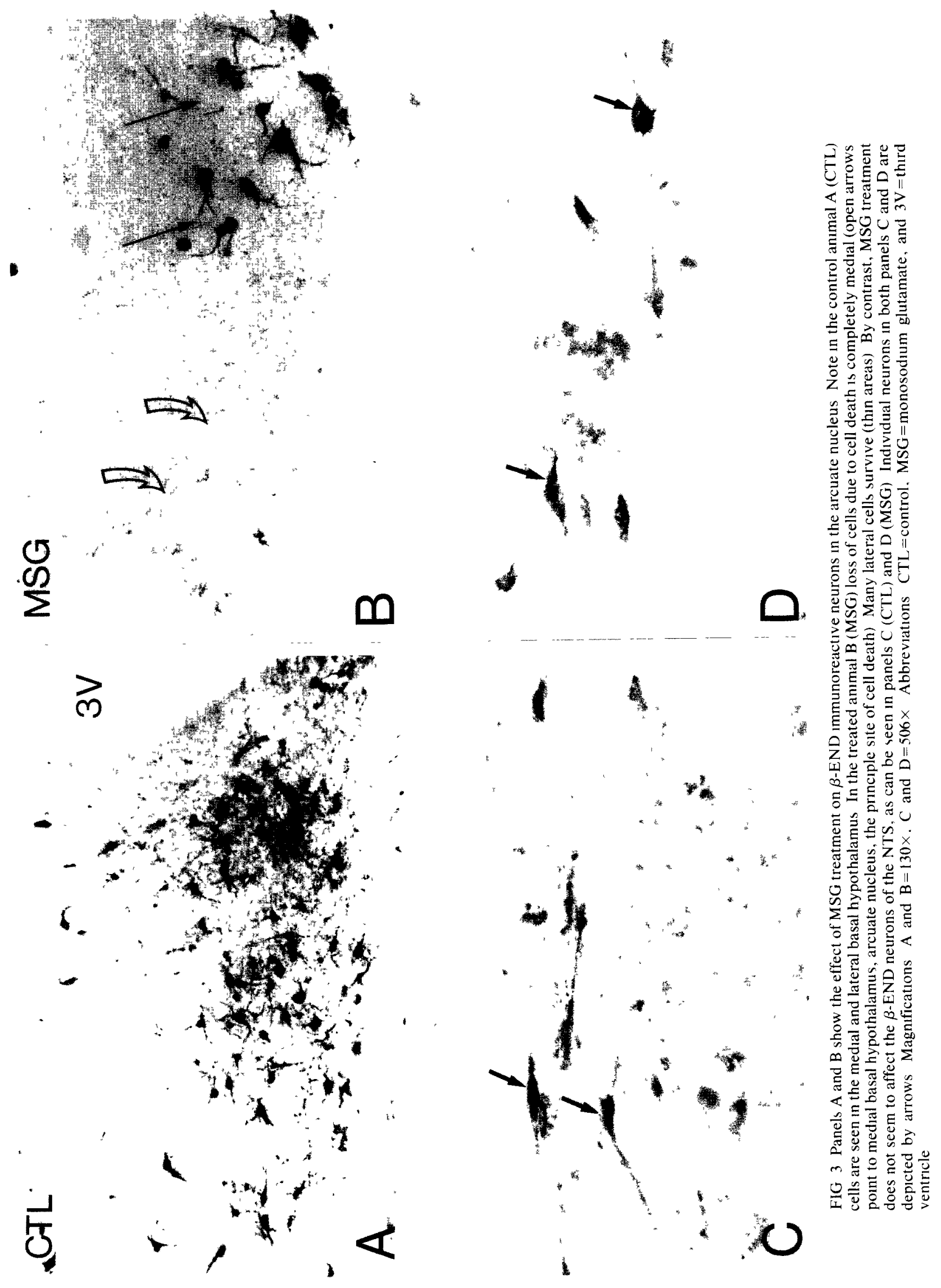




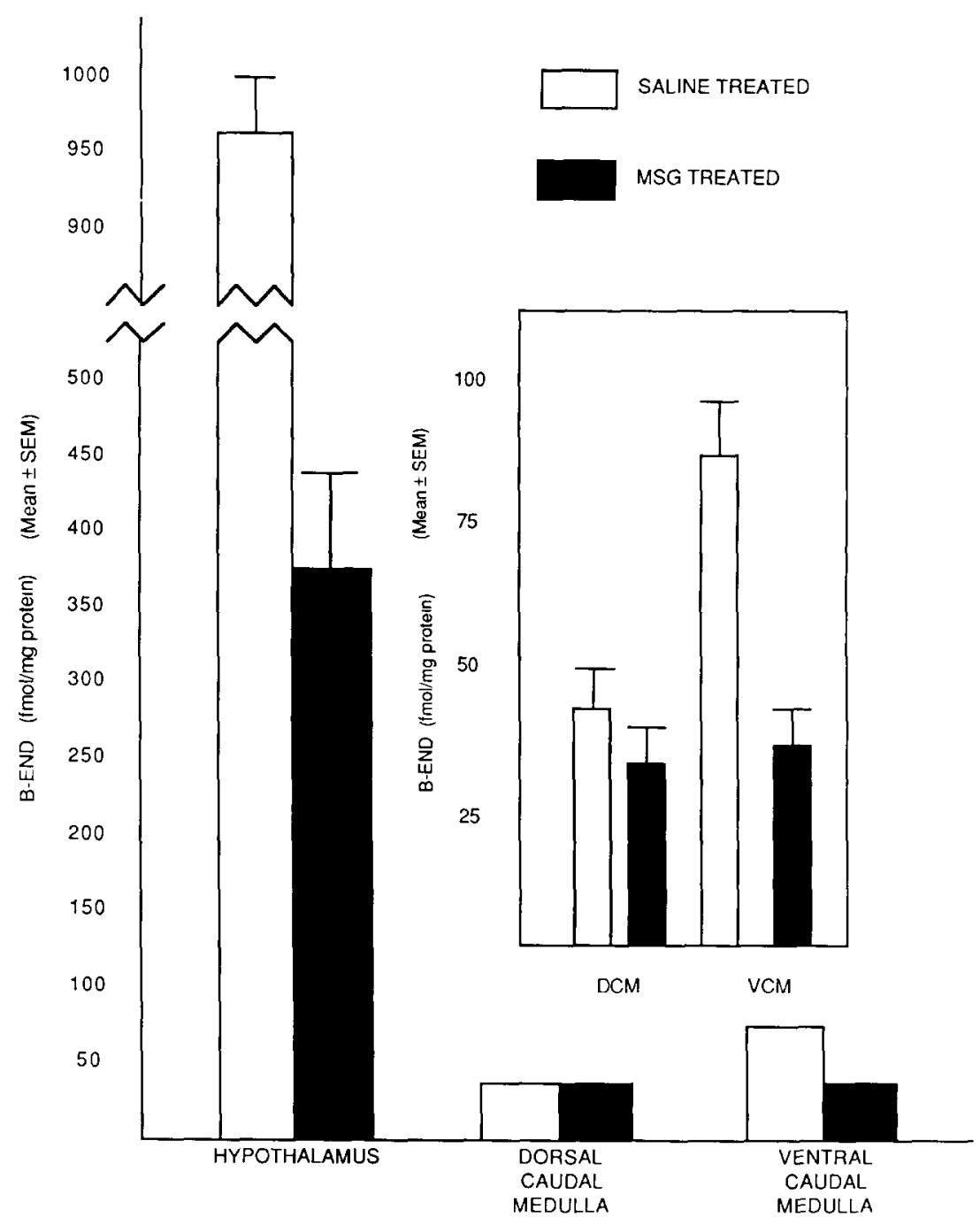

FIG. 4 Beta-endorphın-lıke ımmunoreactıvity (fmol/mg proteın) in MSG versus control rats Unshaded bar represents salıne control anımals, shaded bar represents MSG anımals $\mathrm{N}=6$ per area per conditıon $\mathrm{fmol} / \mathrm{mg}$ proteın $=$ femtomoles per milligrams of protein

basal hypothalamus were spared and appeared to have increased in size Although $\beta$-END staining cell bodies in the dorsal caudal medulla did not appear to be affected either in number or size, there were significant alterations in the levels of $\beta$-END immunoreactivity using radioimmunoassay techniques. Of note, $\beta$-END decreased significantly in the ventral caudal medulla (VCM) without a concomitant decrease in the dorsal caudal medulla (DCM).

The lack of a decrease in the levels of $\beta$-END immunoreactivity in the DCM would support the lack of a decrease in cell number in the nucleus tractus solitarius as demonstrated by immunocytochemistry. If all the material within the VCM originated from the DCM, e $g$, nucleus tractus solitarius cell bodies, one would expect that the levels of $\beta$-END in the VCM in MSG-treated versus control anımals would not decrease, as well. The finding of a significant drop in $\beta$-END levels within the VCM suggests that this material originates from an additional site other than the dorsal caudal medulla, such as the arcuate nucleus. With cardiovascular and respiratory centers present in VCM areas, the hypothalamus could modulate physiological functionıng origınating from these areas via these projections. Such "distant" versus "proximal" innervations would allow subtle but important modulations

While alterations in the levels of $\alpha$-MSH immunoreactivity in the hypothalamus paralleled those seen with $\beta$-END, alterations within the caudal medulla were quite different. Among MSG-treated anımals, a drop in $\alpha$-MSH levels comparable to $\beta$-END levels in VCM was not noted. In fact, $\alpha$-MSH levels in the VCM remained unchanged, while $\alpha$-MSH levels in the DCM rose significantly. One can only speculate as to why the alterations in $\alpha$-MSH levels are different than those of $\beta$-END. Two speculations are: First, the distribution of end products of pro-opiomelanocortin (POMC)-containing cells within the dorsal caudal medulla (nucleus tractus solitarius) may be regionally specific. This same logic may also apply to material originating from outside the dorsal caudal medulla, 1.e., the arcuate nucleus or possibly other areas of the brain. This might explain on an anatomical basis why there are differences in levels fol- 


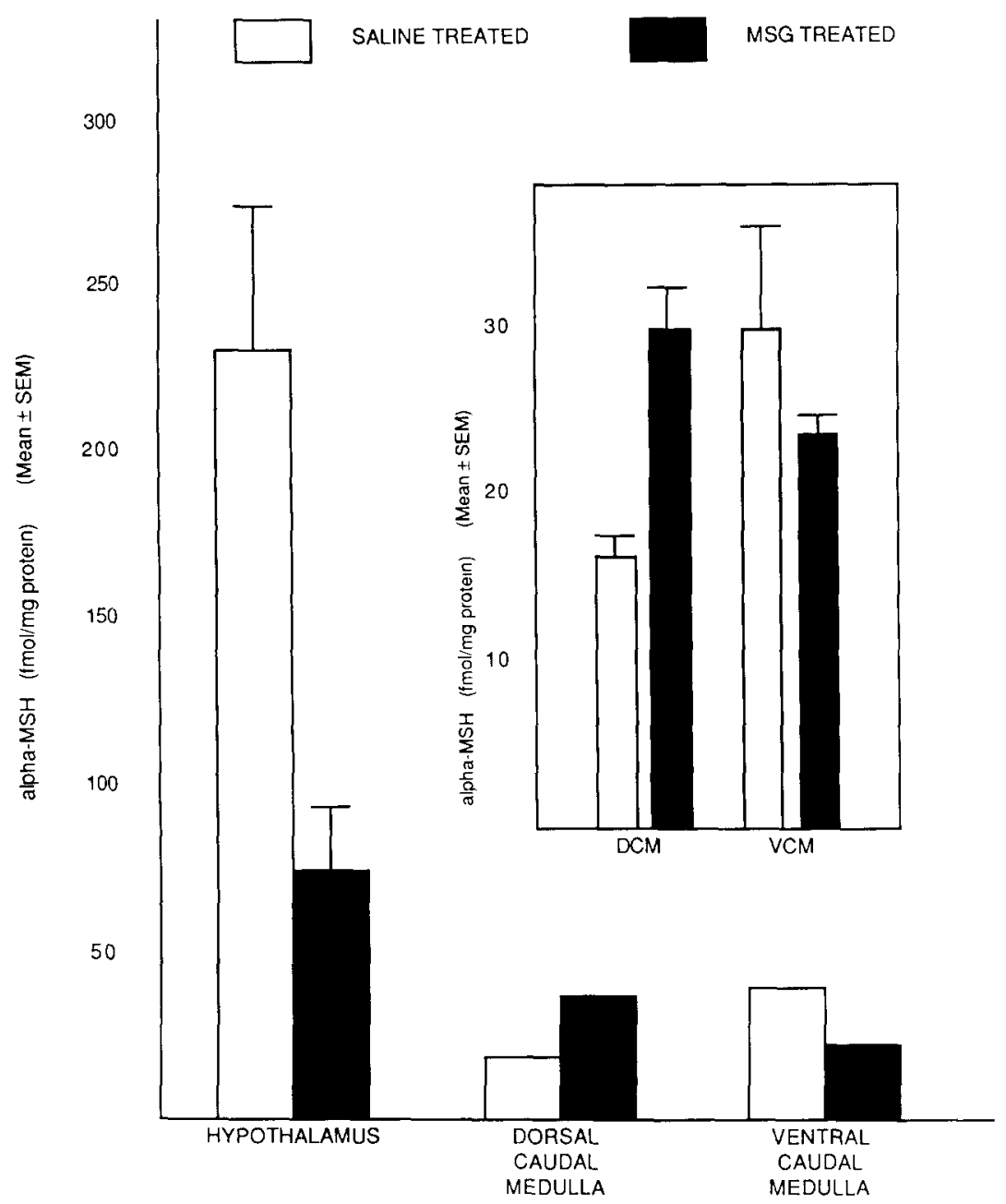

FIG 5 Apha-MSH-lıke immunoreactıvity (fmol/mg proteın) in MSG versus control rats Unshaded bar represents salıne control anımals, shaded bar represents MSG anımals $\mathrm{N}=6$ per area per condition $\mathrm{fmol} / \mathrm{mg}$ protein $=$ femtomoles per milligrams of protem

lowing the lesioning of the medial hypothalamus Second, on a biochemical basis, the differences may be due to an alteration in the rates of metabolism, either in production or in breakdown.

The alterations in the levels of $\alpha$-MSH are further complicated by the identıfication of the alpha-2 group within the lateral hypothalamic area $[9,16]$ These cell bodies have been identıfied as being a separate group which contain $\alpha$-MSH, yet no other POMC-derived material [20]. Studies have suggested that this cell group contains $\alpha$-MSH-like material, not "true" $\alpha$-MSH [9] The implication of this finding is that the $\alpha$-MSH identified within the caudal medulla, both DCM and VCM, may represent a combination of POMC-derived $\alpha$-MSH, originating from the dorsal caudal medulla (NTS) and the medial basal hypothalamus (arcuate nucleus), and an $\alpha$-MSH-like material onginatıng from the alpha- 2 cell group withın the lateral hypothalamus

Although these explanations might explain steady state levels of $\alpha$-MSH in MSG-lesioned animals or a differential decrease, as was found with $\beta$-END, there remains the question of why $\alpha$-MSH levels increased in DCM among MSGtreated anımals versus control animals Any explanation is flawed by the lack of knowledge of the site of origin of the $\alpha$-MSH immunoreactive material, whether "true $\alpha$-MSH" or " $\alpha$-MSH-like." Nevertheless, there are two explanations that can be put forth to explain why post MSG levels of $\alpha$-MSH increased (1) The increase represents the impact of the earlıer lesion, yet does not reflect current need; and (2) The increase is reflective of an increased need of $\alpha$-MSH for the current homeostasis of the system. In regard to the first explanation, $\alpha$-MSH has been reported to be a trophic agent in the brain $[8,17,18]$. Cells within the dorsal caudal medulla (NTS) responsible for the modulation of respiratory and cardiovascular functioning, might be influenced by the trophic action(s) of $\alpha$-MSH during development. Therefore, increased levels of $\alpha$-MSH in the DCM could be explaned on the basis of the importance of these cells receiving exposure to $\alpha$-MSH during development. Multiple sites, i.e., medial and lateral hypothalamus, and medulla, as well as the alpha-2 cell group within the lateral hypothalamus, could represent a built-in redundancy constituting a fall safe system, which would ensure that $\alpha$-MSH or an $\alpha$-MSH-like material reach the nucleus tractus solıtarius neurons during development. Such an alteration resulting from a lesion of 
other primary sites may remain throughout the life of the anımal. Further studies are obviously needed to determıne the anatomy and biochemistry of these peptudes and their roles during development and in the physiological functioning of the adult

In conclusion, future studies of $\beta$-END material withın the caudal medulla, especially studies which attempt to characterize $\beta$-END forms in this area, must take into account the significant contribution of medial basal hypothalamic POMC-containing neurons to the levels of $\beta$-END in this area. Since this study was not designed to determine the origins of the projections to these areas nor to differentıate $\alpha$-MSH from $\alpha$-MSH-like material, the hypotheses concerning the alterations in the levels of $\alpha-\mathrm{MSH}$ are based on limited information Further studies of the $\alpha$-MSH cells and medial basal hypothalmıc POMC-containıng neurons are needed to clarify the role of these cell groups during development, t.e, do they produce a "trophic" material necessary for the development of caudal medulla neurons, and to determine their biochemical composition and role as physiological modulators in the adult

\section{ACKNOWLEDGEMENTS}

The authors wish to thank Drs Huda Akıl and Stanley Watson (University of Michigan) for generously providing the betaendorphın antıserum, Dr Thomas O'Donohus (formerly of Monsanto) for donatıng the alpha-MSH antıserum, and to acknowledge the assistance of Anne Kisly and Annunciata Porterfield in the preparation of the manuscript

\section{REFERENCES}

1 Alessi, $\mathbf{N}$ and $\mathrm{H}$. Khachaturian Postnatal development of beta-endorphin immunoreactivity in the medulla oblongata of rat Neuropeptides 5: 473-476, 1985

2 Alessı, N E and P Quinlan Postnatal development of ACTH and alpha-MSH in the medulla oblongata of rat. Alpha-MSH is the predominant peptıde Peptıdes 6: 137-141, 1985.

3 Cahill, C A, J D Matthews and $\mathrm{H}$ Akıl Human plasma beta-endorphin-lıke peptıdes A rapıd, high recovery extraction technique and valıdation of radiommunoassay $J$ Clin Endocrinol Metab 56: 992-997, 1983

4 Dores, R., M Jain and $\mathrm{H}$ Akıl. Characterization of the form of $\beta$-endorphin and alpha-MSH in the caudal medulla of the rat and guinea pig Brain Res 377: 251-260, 1986

5 Eskay, R. L, M. L. Brownsteın and R T Long Alphamelanocyte-stımulating hormone: Reduction in adult rat brain after monosodium glutamate treatment of neonates Science 205: 824-829, 1979

6 Glowinskı, J and L L Iversen Regional studies of catecholamines in the rat brain I The disposition of ${ }^{3} \mathrm{H}$-norepinephrine, ${ }^{3} \mathrm{H}$-dopamine and ${ }^{3} \mathrm{H}$-DOPA in various regions of the brain $J$ Neurochem 13: 655-669, 1966

7 Goldschmidt, R B and O Steward. Neurotoxic effects of colchicine. Differential susceptibility of CNS neuronal populattons Neurosciences 7: 695-714, 1982

8 Honnebier, $W$ J and D F Swabb Influence of alphamelanocyte-sitmulatıng hormone (alpha-MSH), growth hormone (GH) and fetal brain extracts on intrauterine growth of fetus and placenta in the rat $J$ Obstet Gynecol Nernatal Nurs 81: 439-447, 1974

9. Khachaturian, H , H Akıl, M J Brownsteın, J W Olney, K $\mathrm{H}$ Volgt and S. J Watson Further characterization of the extra-arcuate alpha-melanocyte stımulatıng hormone-like material in hypothalamus biochemical and anatomical studies Neuropeptudes 7: 291-313, 1986

10 Khachaturian, H, M E Lewis, V Hollt and S J Watson Telencephalıc enkephalınergic systems in the rat brain $J$ Neurosci 3: 844-855, 1983

11 Khachaturian, H , M E Lewis, $\mathrm{K}$ Tsou and S. J Watson Beta-endorphin, alpha-MSH, ACTH, and related peptıdes In Handbooh of Chemical Neuroanatomy, Vol 4 GABA and Neuropeptides in the CNS, Part I, edited by A Bjorklund and T Hokfelt Amsterdam Elsevier Science Publishers B V., 1985
12 Lowry, O H , N Y Rosebrough, A L Farr and R J Randall. Protein measurement with the Folin phenol reagent. $J \mathrm{Biol}$ Chem 193: 265-275, 1951

13 Nemeroff, C B , L. D Grant, G Bissette, N E Gregory, L E Harrell and A J Prange Growth, endocrinological and behavtoral deficits after monosodium glutamate in the neonatal rat Possible involvement of arcuate dopamine neuron damage Psichoneuroendocrmology 2: 179-196, 1977

14 Nemeroff, C B, M A Lipton and J S Kizer Models of neuroendocrine regulation. Use of monosodium glutamate as an investıgational tool Dev Neurosci 1: 102-109, 1977

15 Olney, J W Brain lesions, obesity, and other disturbances in mice treated with monosodium glutamate Stience 164: 719721,1969

16 Saper, C B, H Akıl and S J Watson Lateral hypothalamic innervation of the cerebral cortex Immunoreactive stainıng for a peptıde resembling but immunochemically distinct from pitu1tary/arcuate $\alpha$-melanocyte stımulating hormone Bran Res Bull 16: $107-120,1986$

17 Swaab, D F and W J Honnebier The influence of removal of the fetal rat brain upon intrauterine growth of the fetus and the placenta and on gestation length $J$ Obstet Gynecol Neonatal Nurs 80: 589-597, 1973

18 Swaab, D F, M Visser and F J H Tilders Stımulation of intrauterıne growth in rat by alpha-melanocyte-stımulatıng hormone J Endoc rinol 70: 445-455. 1976

19 van der Kooy, D, L Y Koda, J. F. McGinty, C R Gerfen and $F \mathrm{E}$ Bloom The organization of projections from the cortex, amygdala, hypothalamus to the nucleus of solitary tract in the rat J Comp Neurol 224: 1-24, 1984

20 Watson, S. J. and H Akıl Alpha-MSH in rat brain Occurrence withın and outside of beta-endorphın neurons Bran Res 182: 217-233, 1980 